\title{
QUERCETIN - A FLAVONOID WITH A HIGH HEALTH-PROMOTING POTENTIAL
}

\author{
KWERCETYNA - FLAWONOID O DUŻYM POTENCJALE PROZDROWOTNYM
}

Summary. Flavonoids are an important group of bioactive compounds with a high antioxidant potential. Among them, one of the most common components is quercetin, belonging to the flavonols group. The main sources of quercetin are: capers, chokeberries, onions, chia seeds, honey and elderberries. This flavonoid shows a number of health-promoting properties, such as lowering blood sugar level, improving blood lipid profile, lowering blood pressure, and antimicrobial and antiplatelet activity.

Key words: quercetin, flavonoids, bioactive compounds, health-promoting properties, antioxidant potential

\section{Introduction}

Flavonoids are a group of natural substances belonging to polyphenols, present first of all in plant raw materials: fruits, vegetables, herbs, cereals, as well as drinks (tea, coffee, wine). More than 10,000 flavonoids have been identified in nature (Dixon and Pasinetti, 2010); among them there are numerous responsible for an attractive colour or scent of flowers, fruits, or leaves. The compounds also play a protective function in the world of plants. They protect against a harmful activity of pathogenes or UV radiation. Moreover, flavonoids prevent from the occurrence of oxidative stress, owing to their antioxidative properties (Jasiński et al., 2009). The characteristic feature in their structure is the occurrence of two aromatic rings, bound by a tricarbon bond, which is created by a double bond system between the carbon atoms and carbonyl group. In the process of the synthesis of flavonoids, it is transformed into heterocyclic ring containing oxygen, building the system of pyran or pyron. The possibility of the occurrence of numerous chemical reactions (hydroxylase, glycosylation, acylation, methoxylase) with 
Kulczyński, B., Gramza-Michałowska, A., Sidor, A. (2016). Quercetin - a flavonoid with a high health-promoting potential. Nauka Przyr. Technol., 10, 3, \#29. DOI: 10.17306/J.NPT.2016.3.29

the participation of carbons present in aromatic rings, as well as heterocyclic ring, determines a wide biodiversity of the compounds group (Kobylińska and Janas, 2015a, $2015 b$ ). Table 1 contains a classification of substances belonging to flavonoids, taking into account differences in their structural constitution.

Table 1. Classification of flavonoids and their common food sources (Bhagwat et al., 2013; Kumar and Pandey, 2013; Narayana et al., 2001)

Tabela 1. Klasyfikacja flawonoidów oraz źródła ich występowania w żywności (Bhagwat i in., 2013; Kumar i Pandey, 2013; Narayana i in., 2001)

\begin{tabular}{|c|c|c|}
\hline $\begin{array}{l}\text { Group } \\
\text { Grupa }\end{array}$ & $\begin{array}{l}\text { Compound } \\
\text { Związek }\end{array}$ & $\begin{array}{c}\text { Source } \\
\text { Źródło występowania }\end{array}$ \\
\hline $\begin{array}{l}\text { Flavones } \\
\text { Flawony }\end{array}$ & $\begin{array}{l}\text { Apigenin - Apigenina } \\
\text { Luteolin - Luteolina } \\
\text { Diosmin - Diosmina } \\
\text { Tangeretin - Tangeretyna } \\
\text { Nobiletin - Nobiletyna }\end{array}$ & $\begin{array}{l}\text { Parsley, celery, red pepper, pepper, buckwheat, } \\
\text { tomato peel } \\
\text { Zielona pietruszka, seler, czerwona papryka, pieprz, } \\
\text { gryka, skórka pomidora }\end{array}$ \\
\hline $\begin{array}{l}\text { Flavanones } \\
\text { Flawanony }\end{array}$ & $\begin{array}{l}\text { Naringenin - Naryngenina } \\
\text { Hesperidin - Hesperydyna }\end{array}$ & $\begin{array}{l}\text { Grapefruit, lemon, orange } \\
\text { Grejpfrut, cytryna, pomarańcza }\end{array}$ \\
\hline $\begin{array}{l}\text { Flavonols } \\
\text { Flawonole }\end{array}$ & $\begin{array}{l}\text { Quercetin - Kwercetyna } \\
\text { Kaempferol - Kemferol } \\
\text { Myricetin - Mirycetyna } \\
\text { Fistein - Fisteina } \\
\text { Morin - Moryna } \\
\text { Rutin - Rutyna } \\
\text { Galangin - Galangina } \\
\text { Rhamnetin - Ramnetyna }\end{array}$ & $\begin{array}{l}\text { Onion, apple, kale, leek, tomato, broccoli, black } \\
\text { grape, blueberry } \\
\text { Cebula, jabłko, jarmuż, por, pomidor, brokuł, czarne } \\
\text { winogrono, jagoda }\end{array}$ \\
\hline $\begin{array}{l}\text { Flavan-3-ols } \\
\text { Flawan-3-ole }\end{array}$ & $\begin{array}{l}\text { Catechin - Katechina } \\
\text { Epicatechin - Epikatechina } \\
\text { Epigallocatechin - Epigallokatechina }\end{array}$ & $\begin{array}{l}\text { Cocoa, apricot, cherry, peach, red wine, cider, black } \\
\text { and green tea, blackberry, apple } \\
\text { Kakao, morela, wiśnia, brzoskwinia, czerwone wino, } \\
\text { cydr, czarna i zielona herbata, jeżyna, jabłko }\end{array}$ \\
\hline $\begin{array}{l}\text { Isoflavones } \\
\text { Izoflawony }\end{array}$ & $\begin{array}{l}\text { Daidzein - Daidzeina } \\
\text { Genistein - Genisteina } \\
\text { Formononetin - Formononetyna } \\
\text { Biochanin - Biochanina }\end{array}$ & $\begin{array}{l}\text { Soybean, tofu, tempeh, soy milk } \\
\text { Soja, tofu, tempeh, mleko sojowe }\end{array}$ \\
\hline $\begin{array}{l}\text { Anthocyanins } \\
\text { Antocyjany }\end{array}$ & $\begin{array}{l}\text { Cyanidin - Cyjanidyna } \\
\text { Pelargonidin - Pelargonidyna } \\
\text { Malvidin - Malwidyna }\end{array}$ & $\begin{array}{l}\text { Blueberry, black currant, black grape, plum, cherry, } \\
\text { strawberry, red wine, red cabbage, cranberry } \\
\text { Jagoda, czarna porzeczka, czarne winogrono, śliwka, } \\
\text { wiśnia, truskawka, czerwone wino, czerwona kapusta, } \\
\text { żurawina }\end{array}$ \\
\hline
\end{tabular}


Kulczyński, B., Gramza-Michałowska, A., Sidor, A. (2016). Quercetin - a flavonoid with a high health-promoting potential. Nauka Przyr. Technol., 10, 3, \#29. DOI: 10.17306/J.NPT.2016.3.29

The compounds present a wide spectrum of health-promoting properties, that is why they are a significant element of balanced human diet. In some literature publications, flavonoids are called one common name: vitamin P (Sokoloff et al., 1951). It is claimed that their function is: hypoglycemic, hypolypemic, antineoplastic, hypotensional, antiinflammatory, anti-aggregation, or antimicrobial (Kozłowska and Szostak-Węgierek, 2014; Lee et al., 2007). The below work is focused on presenting the occurrence sources, as well as discussing the therapeutic properties of quercetin aglicon and its glycoside derivatives, belonging to the group of flavonoids.

\section{Quercetin - general characteristics}

As it has been mentioned earlier, quercetin $\left(3,3^{\prime}, 4^{\prime}, 5,7\right.$-pentahydroxyflavonoid) is the main flavonoid occurring in numerous edible plants. The compound is regarded as one of the strongest antioxidants of plant origin (Egert et al., 2008). It occurs in nature, first of all, in the form of glycosides. The most common of them all is quercetin-3-O-rutinoside (rutin), in which the sugar component is disaccharide composed of glucose and rhamnose (Jowsa et al., 2008). Quercitrin (3-rhamnoside of quercitin), isoquercitrin (3-glucoside of quercetin), avicularin (3-arabinoside of quercetin), spiraeoside (4-glucoside of quercetin), hyperside (3-galactoside of quercetin) are listed among the derivatives of quercetin. Quercetin is also the basis of other flavonoids biosynthesis, such as hesperidin, naringenin, as well as tangeretin (Jowsa et al., 2008; Lakhanpal and Rai, 2007; Materska, 2008). The presence of hydroxyl groups in a molecule of quercetin makes it display its potent antioxidative properties (Jakubowicz-Gil, 2012).

A potential health-promoting activity of quercetin is, to a high degree, dependent upon the compound's bioavailability after its consumption. It has been proved in numerous cases that the sugar part of a molecule determines the level of quercetin absorption (Egert et al., 2008). A higher level of assimilation is observed in the case of glicosides of quercetin (52\%), compared to free form of aglycon (20\%) (Jowsa et al., 2008). The reason is, most probably, the involvement of $\left(\mathrm{Na}^{+}\right)$-dependent glucose carrier (SGL-1) in the process of active transportation via the small intestine wall (Materska, 2008). It was observed that bromelain, an enzyme present in pineapple, increases the potential of quercetin absorption (Shoskes et al., 1999). The intestine non-absorbed consumed part of quercetin undergoes transformations in the large intestine, utilising the present intestine microflora. The following metabolic products are its effect: phenylacetic and phenylpropionic acids and their derivatives, including 3-metoxy-4-hydroxyphenylacetic acid (homovanillic acid) (Jakubowicz-Gil, 2012). It was noted that the half-life period of quercetin equalls approx. $25 \mathrm{~h}$ and its elimination from the organism is additionally delayed by a high-fat diet (Lesser et al., 2004; Young et al., 1999).

\section{Food-origin quercetin sources}

A daily supply of quercetin in a typical western diet is predicted at the level of 0-30 $\mathrm{mg}$, whereas the median of consumption equals $10 \mathrm{mg}$ (Egert et al., 2008). According to 
Kulczyński, B., Gramza-Michałowska, A., Sidor, A. (2016). Quercetin - a flavonoid with a high health-promoting potential. Nauka Przyr. Technol., 10, 3, \#29. DOI: 10.17306/J.NPT.2016.3.29

the literature data, quercetin makes $68-73 \%$ of all the flavonoids consumed by western societies (Islam et al., 2014). Those who eat a lot of vegetables and fruits abundant in flavonoids (apples, tomatoes, onions) may be delivering even $200-500 \mathrm{mg}$ of the component to the organism per day (Russo et al., 2012). Quercetin is present in various plant parts: fruits, flowers, leaves, seeds, as well as shoots and roots (Duda-Chodak et al., 2009; Kobylińska and Janas, 2015a). Its most abundant sources are: capers, onions, asparagus, green peas, red lettuce leaves, honey, chokeberry, or elderberry (Table 2). In the literature observable differences concerning the content of quercetin in the same plant products are presented. This divergence may result from numerous factors such as: fruit maturity level, cultivation system, genetic and environmental (temperature, insolation, precipitation) factors (Bhagwat et al., 2013; Kobylińska and Janas, 2015a).

Table 2. Quercetin's food sources (Bhagwat et al., 2013)

Tabela 2. Źródła występowania kwercetyny w żywności (Bhagwat i in., 2013)

\begin{tabular}{|l|c|}
\hline \multicolumn{1}{|c|}{ Product } & $\begin{array}{c}\text { Quercetin content (mg per 100 g) } \\
\text { Zawartośc kwercetyny (mg w 100 g) }\end{array}$ \\
\hline 'Red Delicious' apple with peel - Jabłko 'Red Delicious' ze skórką & 3.86 \\
Yellow onion - Cebula żółta & 21.40 \\
Red onion - Cebula czerwona & 31.77 \\
Chokeberry - Aronia & 18.53 \\
Caper - Kapar & 233.84 \\
Elderberry fruit - Owoc czarnego bzu & 26.77 \\
Oregano, fresh - Oregano świeże & 7.30 \\
Oregano, dried - Oregano suszone & 42.00 \\
Cranberry, raw - Żurawina świeża & 14.83 \\
Cranberry, dried - Żurawina suszona & 4.50 \\
Cranberry juice - Sok z żurawiny & 16.41 \\
Fig - Figa & 5.47 \\
Goji berry, dried - Jagoda goji suszona & 13.60 \\
Spinach - Szpinak & 3.97 \\
Chia seeds - Nasiona chia & 18.42 \\
Bee pollen - Pyłek pszczeli & 20.95 \\
Cocoa powder - Kakao w proszku & 3.37 \\
Green pea - Zielony groszek & 14.27 \\
Asparagus - Szparag & 13.98 \\
Red lettuce leaves - Liście czerwonej sałaty & 11.90 \\
\hline
\end{tabular}


Kulczyński, B., Gramza-Michałowska, A., Sidor, A. (2016). Quercetin - a flavonoid with a high health-promoting potential. Nauka Przyr. Technol., 10, 3, \#29. DOI: 10.17306/J.NPT.2016.3.29

\section{Health-promoting properties}

Numerous published scientific investigations indicate wide therapeutic activities of quercetin. The below part of the paper presents the carried out literature review comprising the influence of the discussed compound on human health.

\section{Antidiabetic activity}

Numerous available investigations, discussing the impact of quercetin supply on the values of carbohydrates metabolism parameters, are available. The experiment conducted by Rifaai et al. (2012) revealed the hypoglycemic properties of quercetin. The experimental rats with streptozotocin induced diabetes were daily administered $25 \mathrm{mg}$ of quercetin $\left(3,5,7,3^{\prime}, 4^{\prime}\right.$-pentahydroxyflavon) per $1 \mathrm{~kg}$ of body mass, by intraperitoneal injections, for 30 days. It was found, after the experiment, that the administration of flavonoids caused a decrease of glucose concentration in blood $(4.6 \mathrm{mmol} / \mathrm{l})$, compared to the group deprived of the addition $(21.3 \mathrm{mmol} / 1)$. The obtained differences were statistically significant. The result of the research is convergent with the results from Hatware and Annapurna's (2014) experiment. The model of their experiment assumed the oral manner of administering $25 \mathrm{mg} / \mathrm{kg}$ of body mass of quercetin to rats, as well as intraperitoneally $10 \mathrm{mg} / \mathrm{kg}$ of body mass. The examination was conducted on individuals with induced type I and II diabetes. After the supply of the bioactive compound, the level of glucose in blood was measured for the next $12 \mathrm{~h}$. It turned out, that after the time the oral administration of quercetin evoked sugar concentration reduction, compared to the initial value, both in the individuals with diabetes I (by 65.05\%), and the ones suffering from diabetes II (by $65.93 \%$ ). Hypoglycemic activity was also observed in the case of intraperitoneal supply of the flavonoid. A decrease of the glucose level in blood by $56.58 \%$ in the individuals with diabetes I and $71.61 \%$ in those suffering from diabetes II (Hatware and Annapurna, 2014) was noted. Jeong et al. (2012) obtained interesting results, too. During their experiments they administered quercetin at 0.04 or $0.08 \%$ of the feed mass for 6 weeks to mice suffering from diabetes II. It was further observed that the application brought about a reduction in glucose concentration in blood by respectively 15 and $31 \%$, compared to the control group. The decrease in the level of sugar in blood in the group getting $0.08 \%$ of quercetin was statistically higher than in the group getting $0.04 \%$ of the addition. Simultaneously there was a reduction of insulin resistance coefficient (HOMA-IR) in the group of the individuals consuming flavonoids, compared to the mice control group. However, no statistically significant differences were spotted between the animal groups to which various quercetin concentrations were administered. Moreover, statistically higher level of adiponectin - a protein released by adipose tissue and responsible for increasing the sensitivity of tissues to insulin (Jeong et al., 2012), was noted in individuals given $0.08 \%$ quercetin dose. Another experiment, with rats eating for 7 weeks feed containing $0.08 \%$ quercetin, observed a statistically significant decrease of glycated haemoglobin concentration, in respect to the investigated flavonoid addition deprived group. On the other hand, no differences in the blood insulin concentration were observed (Kim et al., 2011). A beneficial effect of quercetin activity on the carbohydrate metabolism was also confirmed by 
Kulczyński, B., Gramza-Michałowska, A., Sidor, A. (2016). Quercetin - a flavonoid with a high health-promoting potential. Nauka Przyr. Technol., 10, 3, \#29. DOI: 10.17306/J.NPT.2016.3.29

Shetty et al. (2004), in the experiment they conducted. They proved that administering of quercetin to rats suffering from diabetes, in the quantity of $1 \mathrm{~g} / \mathrm{kg}$ of feed mass, brought about an improvement in the animals' health condition, decreasing the volume of the secreted urine and diminishing sugar secretion in urine, as well as lowering the glucose concentration in blood on an empty stomach (Shetty et al., 2004). Then, the research performed by Vessal et al. (2003) showed that administering quercetin to rats at the dose of $15 \mathrm{mg} / \mathrm{kg}$ of body mass resulted in an increase in enzymes activity: hexokinase and glucokinase, responsible for the uptake of glucose from blood, which prevents from emerging of hyperglycemia (Vessal et al., 2003).

\section{Hypolypemic properties}

A description of an influence of quercetin on the lipid metabolism of the organism has been the focus of numerous investigations. The experiment suggested by Jeong (2012) consisted in administering quercetin at 0.04 or $0.08 \%$ of the feed mass for 6 weeks to mice suffering from diabetes II. It proved that the flavonoid addition brought about a decrease in the concentration of triglycerides, as well as of total cholesterol in blood. Parallel to it, an increase of the concentration of HDL fraction cholesterol was observed. A similar, beneficial impact on the lipid blood parameters was noted in the research carried out by Bashir (2014). After an 8-week supplementation with quercetin at the dose of $25 \mathrm{mg} / \mathrm{kg}$ per day, a decrease was noticed in the level of the concentration of total, and LDL fraction cholesterol, as well as triglycerides, both in blood, and in homogenates of the liver of rats suffering from diabetes, with a simultaneous increase of the level of HDL fraction cholesterol. The hypolypemic activity of quercetin is also confirmed by the research conducted by Jadhav and Puchchakayala (2012), who noted a decrease in the concentration of triglycerides and total cholesterol in blood, after the flavonoid had been administered, compared to the control group deprived of the bioactive compound. However, the statistically significant differences were observed exclusively in the case of the reduction of the total cholesterol level.

Another interesting experiment was carried out by Oliveira et al. (2007) who compared an impact of a 30-day long supply of various flavonoids (quercetin, rutin, naringenin, morin) at $30 \mathrm{mg}$ a day, on the lipid level in the blood of rats with induced hypercholesterolemia. The researchers noted the highest level of total cholesterol reduction $(30.34 \%)$ in the case of quercetin supplementation, the lowest for morin $(19.03 \%)$. The concentration of triglycerides in blood was also lowered. The supply of quercetin influenced the reduction of the above mentioned parameter by $43.61 \%$, whereas the most effective result was achieved after morin had been consumed (reduction by 49.97\%). It is interesting that a decrease of the concentration of HDL fraction cholesterol was observed after the consumption of all of the kinds of the researched flavonoids. However, exclusively in the case of morin the effect (reduction of concentration by $21.60 \%$ ) was statistically significant compared to the control group. Similar results were obtained by Ragab et al. (2014) in their experiments. They proved that the daily supply of quercetin at $50 \mathrm{mg} / \mathrm{kg}$ of body mass for a 6-week period improved the blood lipid parameters in rats on a high-fat sucrose-rich diet. After the nutrition intervention had been carried out, there was a statistically significant reduction in the total, and LDL 
Kulczyński, B., Gramza-Michałowska, A., Sidor, A. (2016). Quercetin - a flavonoid with a high health-promoting potential. Nauka Przyr. Technol., 10, 3, \#29. DOI: 10.17306/J.NPT.2016.3.29

fraction cholesterol, as well as triglycerides concentration. There was a minute, statistically insignificant decrease of HDL concentration in relation to the control group.

Attention should be paid to the fact that there are available investigations which unambiguously indicate a lack of an influence of the consumed quercetin on the lipid metabolism. The experiment conducted by Nakamura et al. (2000) proved that everyday oral administration of quercetin at various doses $(0.01 ; 0.05 ; 0.1 ; 0.2 ; 0.5$ and $1.0 \mathrm{~g} / \mathrm{kg})$ for 22 days did not bring about changes in the concentration of total cholesterol, triglycerides, phospholipids in liver and total cholesterol, HDL fraction cholesterol, triglycerides, phospholipids and free fatty acids in blood. Moreover, no significant differences in the level of secreted bilious acids in faeces were observed. Neither in the 15 -week lasting experiment based on the consumption of quercetin at the dose of $0.1 \%$ of a high-cholesterol feed by mice, there were any statistically significant changes in the concentration of total cholesterol or triglycerides in blood, compared to the control group, deprived of the mentioned flavonoid (Kleemann et al., 2011).

\section{Anti-aggregation activity}

The results of numerous investigations have proved that quercetin shows anti-aggregation properties. However, the degree of inhibiting of the aggregation processes taking place under the influence of quercetin, as well as an effective concentration of the flavonoid are still being discussed, and the results coming from many authors are not unambiguous. Beretz et al. (1982) reported that the concentration of quercetin, bringing about $50 \%$ inhibition of colagen-induced thrombocytes aggregation reaches $55 \mu \mathrm{M}$. On the other hand, the research conducted by Raghavendra and Akhilender Naidu (2009) proved that $100 \mu \mathrm{M}$ concentration of quercetin would cause only $1.7 \%$ inhibition of thrombocytes aggregation. Then, the results of other investigations delivered the data which indicate that $100 \mu \mathrm{M}$ concentration of quercetin causes more than 90\% inhibition of collagen-induced thrombocytes aggregation (Mosawy et al., 2013). The available results of other investigations confirm the antiplatelet efficiency of quercetin against the processes of aggregation induced by antagonists of platelets other than collagen. The experiment conducted by Mosawy et al. (2013), found out that full inhibition of arachidonic acid induced platelet aggregation was achieved at $200 \mu \mathrm{M}$ level of quercetin concentration. It was also proved that quercetin causes adenosine diphosphate (ADP) and epinephrine induced platelet aggregation (Islam et al., 2014). A similar activity was observed concerning glycoside of quercetin i.e. rutin (Sheu et al., 2004). On the other hand, the experiment conducted on people showed that quercetin supplementation at the quantity of $1 \mathrm{~g}$ per day for 28 days did not bring about any changes in the thrombosis risk factors compared to the control group (Conquer et al., 1998). Similar conclusions were drawn in the experiment in which the participants consumed $220 \mathrm{~g}$ of onion daily for 7 days. The onion provided $114 \mathrm{mg}$ of quercetin (Janssen et al., 1998).

\section{Hypotensional properties}

Humans and animals-assisted experiments suggest the hypotensional effect of quercetin. It was proved, in the test conducted on rats with provoked arterial hypertension, 
Kulczyński, B., Gramza-Michałowska, A., Sidor, A. (2016). Quercetin - a flavonoid with a high health-promoting potential. Nauka Przyr. Technol., 10, 3, \#29. DOI: 10.17306/J.NPT.2016.3.29

that $10 \mathrm{mg} / \mathrm{kg}$ of quercetin, administered orally for 5 weeks, caused a decrease in the systolic blood pressure by $18 \%$, whereas in the diastolic one by $23 \%$. The hypotensional effect was not observed in rats with norm-tension (Marcus and Safier, 1993). Reduction in blood pressure was also noticed in the experiments with animals which were administered angiotensin (Häckl et al., 2002), as well as in the individuals with aortic valve stenosis (Jalili et al., 2006). The randomized experiments with a double-blind test proved that a daily quercetin supplementation at $730 \mathrm{mg}$ for 28 days decreased systolic (by $7 \mathrm{mmHg}$ ) and diastolic (by $5 \mathrm{mmHg}$ ) blood pressure in patients with hypertension condition of the first degree. However, the activity was not proved in the case of the pre-hypertension patients (Edwards et al., 2007). After a 6-week quercetin supplementation at $150 \mathrm{mg}$ per day dose, a reduction of the systolic blood pressure (by $2.9 \mathrm{mmHg}$ ) was noted in both overweight and obese patients who were also diagnosed to have pre-hypertension condition (Egert et al., 2009). Conquer et al. (1998) observed in their experiments that a 4-week daily $1000 \mathrm{mg}$ quercetin and $200 \mathrm{mg}$ rutin supplementation caused no changes in the blood pressure in norm-tension patients. The available literature data inform that the following mechanisms are responsible for the hypotensional activity of quercetin: decreasing the oxidative stress, impact on the RAA system (renina-angiotensine-aldosterone), as well as improvement in blood vessels functioning owing to an increased bioavailability of nitric oxide (NO) (Larson et al., 2012). As it was proved the vasorelaxant activity is also performed by quercetin metabolites such as: isorhamnetin, tamarexetin, as well as kaempferol (Pérez-Vizcaíno et al., 2002).

\section{Antimicrobial activity}

The literature delivers numerous results of the research devoted to the health-promoting activity of quercetin. The investigation carried out by Özçelik et al. (2006) proved the antibacterial and antifungal activity of quercetin glycoside $(3,7-\mathrm{O}-\alpha-\mathrm{L}-$ -dirhamnoside of quercetin) towards the following microorganisms: Escherichia coli, Pseudomonas aeruginosa, Proteus mirabilis, Klebsiella pneumoniae, Acinetobacter baumannii, Staphylococcus aureus, Bacillus subtilis, Enterococcus faecalis and Candida albicans. The most potent antibacterial properties of quercetin were noted towards Staphylococcus aureus, Enterococcus faecalis and Candida albicans, for which minimal inhibitory concentration was successively $0.5,0.5$ and $1.0 \mu \mathrm{g} / \mathrm{ml}$. Antimicrobial activity was also confirmed in the experiments conducted by Manivannan et al. (2014). As it turned out, quercetin glycoside (2-galusan-3-O- $\alpha$-L-rhamnopyranoside of quercetin) applied in three concentrations: 50, 100 and $200 \mu \mathrm{g}$, inhibited the development of the following bacteria: Staphylococcus aureus, Bacillus subtilis, Sarcina lutea, Escherichia coli, as well as Pseudomonas aeruginosa. The highest antimicrobial activity was observed towards Staphylococcus aureus and Escherichia coli. The higher the concentration of quercetin, the higher the mentioned activity was. On the other hand, no inhibitory action against the development of Candida albicans was observed. The experiment conducted by Woźnicka et al. (2013) proved that morin showed higher antibacterial properties, compared to quercetin, towards Escherichia coli, Pseudomonas aeruginosa and Staphylococcus aureus. Shu et al. (2011) confirmed the inhibitory impact of quercetin on selected pathogenic bacteria: Streptococcus mutans, Streptococcus sobrinus, 
Kulczyński, B., Gramza-Michałowska, A., Sidor, A. (2016). Quercetin - a flavonoid with a high health-promoting potential. Nauka Przyr. Technol., 10, 3, \#29. DOI: 10.17306/J.NPT.2016.3.29

Streptococcus sanguis, Lactobacillus acidophilus, Porphyromonas gingivalis and Actinobacillus actinomycetemcomitans. At the same time, no inhibitory activity towards: Actinomyces viscosus, Actinomyces naeslundii, Fusobacterium nucleatum, Prevotella intermedia and Candia albicans was observed (Shu et al., 2011).

\section{Antioxidative activity}

As it has been mentioned at the beginning of the paper, quercetin is characterized by potent antioxidative properties. During the last dozen or so years a sequence of investigations has been conducted, evaluating the antioxidative potential of the flavonoid. The in vitro experiments by Majewska et al. (2011) showed that quercetin presents a high capacity of free radicals (DPPH) scavenging. The compound in the amount of $50 \mu \mathrm{g}$ scavenged radicals DPPH at the level $79.2 \%$. The efficiency of quercetin was higher compared to the other analysed flavonols: rhamnetin $(62.5 \%)$, isorhamnetin $(60.1 \%)$, as well as flavones: luteolin (62.4\%) and apigenin (7.3\%). Similarly, the experiments conducted by Khanduja and Bhardwaj (2003) confirm the high quercetin capability of neutralizing DPPH radicals. The quercetin concentration at $16.2 \mu \mathrm{M}$ made it possible to reach a decrease in DPPH radicals content by half $\left(\mathrm{IC}_{50}\right)$. The result was identical to the one for myricetin and lower than that for the other compounds: fisetin $(22.5 \mu \mathrm{M})$, catechin $(32.5 \mu \mathrm{M})$, resveratrol $(62.5 \mu \mathrm{M}), \alpha$-tocopherol $(60.0 \mu \mathrm{M})$, kaempferol $(117 \mu \mathrm{M})$ and naringenin $(>250 \mu \mathrm{M})$. The antioxidative quercetin derivatives capacity was analysed in the research of Wiczkowski et al. (2014), who proved the capability of the described compounds (quercetin aglycon, isorhamnetin, 3,4-diglucoside of quercetin, 4-glucoside of quercetin, 3-glucoside of isorhamnetin, 3-glucoside of quercetin) of DPPH radicals scavenging and ABTS cation-radicals reducing. Moreover, the same authors presented superoxide anion-radicals scavenging capacity of selected flavonoids in their photochemiluminescence assay (PCL). The investigations on rats with streptozotocin induced oxidative stress showed that intraperitoneal administration of quercetin at the dose of $15 \mathrm{mg} / \mathrm{kg}$ of body mass for a 4 -week period caused a statistically significant increase in the activity of antioxidative enzymes (catalase, superoxide dismutase, glutathione peroxidase) in pancreatic tissues and a simultaneous decrease of malondialdehyde (MDA) concentration in pancreatic tissues and erytrocytes (Coskun et al., 2005). The results of the investigations were confirmed in a later experiment, in which rats with streptozotocin induced diabetes were administered quercetin also intraperitoneally at the dose of $15 \mathrm{mg} / \mathrm{kg}$ of body mass for a period of either 8 or 16 weeks. A decrease of MDA concentration in the tissues of aorta, heart, spleen, brain, liver, as well as kidneys pith and cortex was observed in individuals taking the flavonoid. A paralell increase of catalase (CAT) and superoxide dismutase (SOD) activity was observed in all the mentioned tissues (Edremitlioglu et al., 2012). Then, it was noticed, in the investigations in which rats on a high-fat sucrose-rich diet were the research model, that the supply of quercetin at the daily dose of $50 \mathrm{mg} / \mathrm{kg}$ of body mass, administered orally for 6 weeks, influenced the statistically significant increase of the superoxide dismutase and catalase activity in the liver of the tested animals. Such an effect was not observed in the case of the blood plasma antioxidative enzymes activity. A significant decrease of lipids perox- 
Kulczyński, B., Gramza-Michałowska, A., Sidor, A. (2016). Quercetin - a flavonoid with a high health-promoting potential. Nauka Przyr. Technol., 10, 3, \#29. DOI: 10.17306/J.NPT.2016.3.29

idation in the liver tissues and blood plasma was reported in the same investigation after quercetin had been administered (Ragab et al., 2014).

\section{Summary}

Derivatives of quercetin are bioactive compounds belonging to the group of flavonoids. They commonly occur in plant products, mainly in capers, onions, asparagus, lettuce, green peas, honey or black elder fruits. Numerous conducted investigations indicate, first of all, its various health-promoting activities, stressing its profitable impact on the organism's lipid and carbohydrate metabolism improvement. Moreover, the compound proves its hypotensional and anti-aggregation (antiplatelet) activity. Quercetin inhibits the development of numerous pathogenic microorganisms e.g. Staphylococcus aureus, Enterococcus faecalis, Bacillus subtilis, Escherichia coli. Its characteristic feature is also a high antioxidative potential. It has been proved that quercetin distinguishes itself by possessing the capability to neutralize free radicals (DPPH, ABTS), as well as to scavenge superoxide anion-radicals. What is more, it has been observed that supplying quercetin derivatives to animals with induced oxidative stress profitably influences an increase of the antioxidative activity of the enzymes of the endogenous antioxidative system.

\section{References}

Bashir, S. O. (2014). Hepatoprotective role for quercetin in diabetic rats: hypolipidemic and antioxidant effects. Med. J. Cairo Univ., 82, 2, 169-178.

Beretz, A., Cazenave, J. P., Anton, R. (1982). Inhibition of aggregation and secretion of human platelets by quercetin and other flavonoids: structure-activity relationships. Agents Actions, $12,3,382-387$.

Bhagwat, S., Haytowitz, D. B., Holden, J. M. (2013). USDA database for the flavonoid content of selected foods. Release 3.1. Beltsville, MD: U.S. Department of Agriculture.

Conquer, J. A., Maiani, G., Azzini, E., Raguzzini, A., Holub, B. J. (1998). Supplementation with quercetin markedly increases plasma quercetin concentration without effect on selected risk factors for heart disease in healthy subjects. J. Nutr., 128, 3, 593-597.

Coskun, O., Kanter, M., Korkmaz, A., Oter, S. (2005). Quercetin, a flavonoid antioxidant, prevents and protects streptozotocin-induced oxidative stress and $\beta$-cell damage in rat pancreas. Pharmacol. Res., 51, 2, 117-123.

Dixon, R. A., Pasinetti, G. M. (2010). Flavonoids and isoflavonoids: from plant biology to agriculture and neuroscience. Plant Physiol. (Bethesda), 154, 453-457.

Duda-Chodak, A., Markiewicz, D., Pierzchalski, P. (2009). The effect of quercetin, chlorogenic acid and epigallocatechin on proliferation of Caco-2 cells. Acta Sci. Pol. Technol. Aliment., 8, $1,63-69$.

Edremitlioglu, M., Andic, M. F., Korkut, O. (2012). Quercetin, a powerful antioxidant bioflavonoid, prevents oxidative damage in different tissues of long-term diabetic rats. Balk. Med. J., $29,49-55$.

Edwards, R. L., Lyon, T., Litwin, S. E., Rabovsky, A., Symons, J. D., Jalili, T. (2007). Quercetin reduces blood pressure in hypertensive subjects. J. Nutr., 137, 11, 2405-2411.

Egert, S., Bosy-Westphal, A., Seiberl, J., Kürbitz, C., Settler, U., Plachta-Danielzik, S., Wagner, A. E., Frank, J., Schrezenmeir, J., Rimbach, G., Wolffram, S., Müller, M. J. (2009). Quercetin 
Kulczyński, B., Gramza-Michałowska, A., Sidor, A. (2016). Quercetin - a flavonoid with a high health-promoting potential. Nauka Przyr. Technol., 10, 3, \#29. DOI: 10.17306/J.NPT.2016.3.29

reduces systolic blood pressure and plasma oxidised low-density lipoprotein concentrations in overweight subjects with a high-cardiovascular disease risk phenotype: a double-blinded, placebo-controlled cross-over study. Br. J. Nutr., 102, 7, 1065-1074.

Egert, S., Wolffram, S., Bosy-Westphal, A., Boesch-Saadatmandi, C., Wagner, A. E., Frank, J., Rimbach, G., Mueller, M. J. (2008). Daily quercetin supplementation dose-dependly increases plasma quercetin concentrations in healthy humans. J. Nutr., 138, 9, 1615-1621.

Häckl, L. P., Cuttle, G., Dovichi, S. S., Lima-Landman, M. T., Nicolau, M. (2002). Inhibition of angiotensin-converting enzyme by quercetin alters the vascular response to bradykinin and angiotensin I. Pharmacology (Basel), 65, 182-186.

Hatware, K., Annapurna, A. (2014). The effect of quercetin on blood glucose levels of normal and streptozotocin induced diabetic (type I and type II) rats. Int. J. Pharm. Chem. Biol. Sci., 4, 3, 613-619.

Islam, M. A., Schmidt, R. W., Gunaseelan, S., Sanchez, A. (2014). An update on the cardiovascular effects of quercetin, a plant flavonoid. Curr. Nutr. Food Sci., 10, 1, 36-48.

Jadhav, R., Puchchakayala, G. (2012). Hypoglycemic and antidiabetic activity of flavonoids: boswellic acid, ellagic acid, quercetin, rutin on streptozotocin nicotinamide induced type 2 diabetic rats. Int. J. Pharm. Pharm. Sci., 4, 2, 251-256.

Jakubowicz-Gil, J. (2012). Kwercetyna w terapii przeciwnowotworowej. Post. Biol. Komórki, 39, 2, 199-216.

Jalili, T., Carlstrom, J., Kim, S., Freeman, D., Jin, H., Wu, T. C., Litwin, S. E., Symons, J. D. (2006). Quercetin-supplemented diets lower blood pressure and attenuate cardiac hypertrophy in rats with aortic constriction. J. Cardiovasc. Pharmacol., 47, 531-541.

Janssen, K., Mensink, R. P., Cox, F. J., Harryvan, J. L., Hovenier, R., Hollman, P. C., Katan, M. B. (1998). Effects of the flavonoids quercetin and apigenin on hemostasis in healthy volunteers: results from an in vitro and a dietary supplement study. Am. J. Clin. Nutr., 67, 2, 255262.

Jasiński, M., Mazurkiewicz, E., Rodziewicz, P., Figlerowicz, M. (2009). Flawonoidy - budowa, właściwości i funkcja ze szczególnym uwzględnieniem roślin motylkowatych. Biotechnologia, 85, 2, 81-94.

Jeong, S.-M., Kang, M.-J., Choi, H.-N., Kim, J.-H., Kim, J.-I. (2012). Quercetin ameliorates hyperglycemia and dyslipidemia and improves antioxidant status in type 2 diabetic $\mathrm{db} / \mathrm{db}$ mice. Nutr. Res. Pract., 6, 3, 201-207.

Jowsa, A., Pawłowska-Góral, K., Talarek, K., Wardas, M. (2008). Biologiczna aktywność kwercetyny. Farm. Przegl. Nauk., 11-12, 18-22.

Khanduja, K. L., Bhardwaj, A. (2003). Stable free radical scavenging and antiperoxidative properties of resveratrol compared in vitro with some other bioflavonoids. Indian J. Biochem. Biophys., 40, 6, 416-422.

Kim, J.-H., Kang, M.-J., Choi, H.-N., Jeong, S.-M., Lee, Y.-M., Kim, J.-I. (2011). Quercetin attenuates fasting and postprandial hyperglycemia in animal models of diabetes mellitus. Nutr. Res. Pract., 5, 2, 107-111.

Kleemann, R., Verschuren, L., Morrison, M., Zadelaar, S., van Erk, M. J., Wielinga, P. Y., Kooistra, T. (2011). Anti-inflammatory, anti-proliferative and anti-atherosclerotic effects of quercetin in human in vitro and in vivo models. Atherosclerosis, 218, 1, 44-52.

Kobylińska, A., Janas, K. M. (2015a). Kwercetyna, ważny flawonoid w życiu roślin. Kosmos, 64, $1,113-127$.

Kobylińska, A., Janas, K. M. (2015b). Prozdrowotna rola kwercetyny obecnej w diecie człowieka. Post. Hig. Med. Dośw., 69, 51-62.

Kozłowska, A., Szostak-Węgierek, D. (2014). Flavonoids - food sources and health benefits. Rocz. Państw. Zakł. Hig., 65, 2, 79-85.

Kumar, S., Pandey, A. K. (2013). Chemistry and biological activities of flavonoids: an overview. Sci. World J., 2013, art. ID 162750. 
Kulczyński, B., Gramza-Michałowska, A., Sidor, A. (2016). Quercetin - a flavonoid with a high health-promoting potential. Nauka Przyr. Technol., 10, 3, \#29. DOI: 10.17306/J.NPT.2016.3.29

Lakhanpal, P., Rai, D. K. (2007). Quercetin: a versatile flavonoid. Internet J. Med. Update, 2, 2, 22-37.

Larson, A. J., Symons, J. D., Jalili, T. (2012). Therapeutic potential of quercetin to decrease blood pressure: review of efficacy and mechanisms. Adv. Nutr., 3, 1, 39-46.

Lee, E.-R., Kang, G.-H., Cho, S.-G. (2007). Effect of flavonoids on human health: old subjects but new challenges. Recent Pat. Biotechnol., 1, 2, 139-150.

Lesser, S., Cermak, R., Wolffram, S. (2004). Bioavailability of quercetin in pigs is influenced by the dietary fat content. J. Nutr., 134, 6, 1508-1511.

Majewska, M., Skrzycki, M., Podsiad, M., Czeczot, H. (2011). Evaluation of antioxidant potential of flavonoids: an in vitro study. Acta Pol. Pharm., 68, 4, 611-615.

Manivannan, R., Prabakaran, K., Ilayaraja, S. (2014). Isolation, identification and antibacterial and wound healing studies of quercetin-3-O- $\alpha$-L-rhamnopyranoside-2"-gallate. Int. J. Appl. Sci. Eng., 12, 2, 99-106.

Marcus, A. J., Safier, L. B. (1993). Thromboregulation: multicellular modulation of platelet reactivity in hemostasis and thrombosis. FASEB J., 7, 6, 516-522.

Materska, M. (2008). Quercetin and its derivatives: chemical structure and bioactivity - a review. Pol. J. Food Nutr. Sci., 58, 4, 407-413.

Mosawy, S., Jackson, D. E., Woodman, O. L., Linden, M. D. (2013). Inhibition of platelet-mediated arterial thrombosis and platelet granule exocytosis by 3',4'-dihydroxyflavonol and quercetin. Platelets, 24, 8, 594-604.

Nakamura, Y., Ishimitsu, S., Tonogai, Y. (2000). Effects of quercetin and rutin on serum and hepatic lipid concentrations, fecal steroid excretion and serum antioxidant properties. J. Health Sci., 46, 4, 229-240.

Narayana, K. R., Reddy, M. S., Chaluvadi, M. R., Krishna, D. R. (2001). Bioflavonoids classification, pharmacological, biochemical effects and therapeutic potential. Indian J. Pharmacol., $33,1,2-16$.

Oliveira, T. T., Ricardo, K. F. S., Almeida, M. R., Costa, M. R., Nagem, T. J. (2007). Hypolipidemic effect of flavonoids and cholestyramine in rats. Lat. Am. J. Pharm., 26, 3, 407-410.

Özçelik, B., Orhan, I., Toker, G. (2006). Antiviral and antimicrobial assessment of some selected flavonoids. Z. Naturforsch. Teil C, 61, 9/10, 632-638.

Pérez-Vizcaíno, F., Ibarra, M., Cogolludo, A. L., Duarte, J., Zaragozá-Arnáez, F., Moreno, L., López-López, G., Tamargo, J. (2002). Endothelium-independent vasodilator effects of the flavonoid quercetin and its methylated metabolites in rat conductance and resistance arteries. J. Pharmacol. Exp. Ther., 302, 1, 66-72.

Ragab, S. M. M., Omar, H. E.-D. M., Abd Elghaffar, S. K., El-Metwally, T. H. (2014). Hypolipidemic and antioxidant effects of phytochemical compounds against hepatic steatosis induced by high fat high sucrose diet in rats. Arch. Biomed. Sci., 2, 1, 1-10.

Raghavendra, R. H., Akhilender Naidu, K. (2009). Spice active principles as the inhibitors of human platelet aggregation and thromboxane biosynthesis. Prostaglandins Leukot. Essent. Fatty Acids, 81, 1, 73-78.

Rifaai, R. A., El-Tahawy, N. F., Saber, E. A., Ahmed, R. (2012). Effect of quercetin on the endocrine pancreas of the experimentally induced diabetes in male albino rats: a histological and immunohistochemical study. J. Diabetes Metab., 3, 3: 182, 1-11.

Russo, M., Spagnuolo, C., Tedesco, I., Bilotto, S., Russo, G. L. (2012). The flavonoid quercetin in disease prevention and therapy: facts and fancies. Biochem. Pharmacol., 83, 1, 6-15.

Shetty, A. K., Rashmi, R., Rajan, M. G. R., Sambaiah, K., Salimath, P. V. (2004). Antidiabetic influence of quercetin in streptozotocin-induced diabetic rats. Nutr. Res., 24, 5, 373-381.

Sheu, J. R., Hsiao, G., Chou, P. H., Shen, M. Y., Chou, D. S. (2004). Mechanisms involved in the antiplatelet activity of rutin, a glycoside of the flavonol quercetin, in human platelets. J. Agric. Food Chem., 52, 4414-4418. 
Kulczyński, B., Gramza-Michałowska, A., Sidor, A. (2016). Quercetin - a flavonoid with a high health-promoting potential. Nauka Przyr. Technol., 10, 3, \#29. DOI: 10.17306/J.NPT.2016.3.29

Shoskes, D. A., Zeitlin, S. I., Shahed, A., Rajfer, J. (1999). Quercetin in men with category III chronic prostatitis: a preliminary prospective, double-blind, placebo-controlled trial. Urology, $54,6,960-963$.

Shu, Y., Liu, Y., Li, L., Feng, J., Lou, B., Zhou, X., Wu, H. (2011). Antibacterial activity of quercetin on oral infectious pathogens. Afr. J. Microbiol. Res., 5, 30, 5358-5361.

Sokoloff, B., Eddy, W. H., Redd, J. B. (1951). The biological activity of flavonoid (vitamin „P”) compound. J. Clin. Invest., 30, 4, 395-400.

Vessal, M., Hemmati, M., Vasei, M. (2003). Antidiabetic effects of quercetin in streptozocin-induced diabetic rats. Comp. Biochem. Physiol. C Toxicol. Pharmacol., 135, 3, 357-364.

Wiczkowski, W., Szawara-Nowak, D., Topolska, J., Olejarz, K., Zieliński, H., Piskuła, M. K. (2014). Metabolites of dietary quercetin: profile, isolation, identification, and antioxidant capacity. J. Funct. Foods, 11, 121-129.

Woźnicka, E., Kuźniar, A., Nowak, D., Nykiel, E., Kopacz, M., Gruszecka, J., Golec, K. (2013). Comparative study on the antibacterial activity of some flavonoids and their sulfonic derivatives. Acta Pol. Pharm., 70, 3, 567-571.

Young, J. F., Nielsen, S. E., Haraldsdóttir, J., Daneshvar, B., Lauridsen, S. T., Knuthsen, P., Crozier, A., Sandström, B., Dragsted, L. O. (1999). Effect of fruit juice intake on urinary quercetin excretion and biomarkers of antioxidative status. Am. J. Clin. Nutr., 69, 1, 87-94.

\section{KWERCETYNA - FLAWONOID O DUŻYM POTENCJALE PROZDROWOTNYM}

Streszczenie. Flawonoidy stanowią ważną grupę związków bioaktywnych, charakteryzujących się dużym potencjałem przeciwutleniającym. Wśród nich jednym z najpowszechniej występujących związków jest kwercetyna. Należy ona do flawonoli. Jej głównym źródłem w pożywieniu są m.in.: kapary, aronia, cebula, nasiona chia, miód czy też owoce czarnego bzu. Kwercetyna wykazuje szereg właściwości prozdrowotnych: obniża poziom cukru we krwi, poprawia profil lipidowy krwi, obniża ciśnienie tętnicze krwi, działa przeciwagregacyjnie oraz przeciwdrobnoustrojowo.

Słowa kluczowe: kwercetyna, flawonoidy, związki bioaktywne, właściwości prozdrowotne, właściwości przeciwutleniające

Corresponding address - Adres do korespondencji:

Bartosz Kulczyński, Katedra Technologii Żywienia Czlowieka, Uniwersytet Przyrodniczy w Poznaniu, ul. Wojska Polskiego 31/33, 60-624 Poznań, Poland, e-mail: bartosz.kulczynski@up. poznan.pl

Accepted for publication - Zaakceptowano do opublikowania:

11.03.2016

For citation - Do cytowania:

Kulczyński, B., Gramza-Michałowska, A., Sidor, A. (2016). Quercetin - a flavonoid with a high health-promoting potential. Nauka Przyr. Technol., 10, 3, \#29. DOI: 10.17306/J.NPT.2016.3.29 